\title{
THE EFFECT OF MARKET ORIENTATION TOWARDS THE COMPETITIVE ADVANTAGE ON PEPPER FARMING ACTIVITY
}

\author{
Evahelda, Astuti Rufti Puji* \\ Department of Agribusiness, University of Bangka Belitung, Indonesia \\ *E-mail: ruftipuji24@gmail.com
}

\begin{abstract}
The number of both domestic and international business actors increases gradually. It creates the challenges faced by the farmers. They need to create competitive advantage on their farming activities. The study aims to i) identify whether market orientation affects competitive advantage, ii) understand whether there is an indirect effect of the market through the post-harvest treatment on competitive advantage, and iii) examine whether the post-harvest treatment is able to increase the influence of the competitive orientation market. Survey was used as the research method involving 60 farmers as the respondents. Structural Equation Modeling (SEM) using smart partial least squares (PLS) was employed to analyze the data. The results showed that competitive advantage was both directly and indirectly influenced by post-harvest treatment and attitude on market orientation. Postharvest treatment played a vital role in influencing the market orientation towards competitive advantage. It required support from farmers in having the attitude on market orientation and from various stakeholders to facilitate and improve the post-harvest treatment so that the product competitiveness could be achieved.
\end{abstract}

\section{KEY WORDS}

Competitive advantage, muntok white pepper, post-harvest treatment.

Pepper becomes one of the biggest agricultural commodities that is produced in Indonesia from the plantation sector. Pepper is a spice that can sustainably be developed and integrated (Direktorat Tanaman Rempah dan Penyegar, 2011). Pepper is also an export commodity which in 2019 contributes USD 134.589 .000 to the national economy. It indicates that the export value has decreased compared with 2017 at USD 235.962.000 (Pusat Data and Sistem Informasi Pertanian Sekretariat Jenderal Kementerian Pertanian, 2019). Bangka Belitung Island Province is one of pepper production centers in Indonesia. The brand of pepper in the province is best known as Muntok White Pepper. The farming activity in the province is run in the form of smallholder plantation (Heryanto \& Nugraha 2018).

The fluctuation of the export price is one of the reasons it occurs. Within the period of April 2019 - March 2020, the price of pepper was at Rp54.000 in April 2019 and decreased gradually in March 2020 at about Rp40.000 (International Pepper Community, 2020). Even though Indonesia has ever experienced to be the top biggest production of pepper in the world, in 2017 Indonesia can only contribute 19\% of global need, lower than Vietnam's contribution to the world at $27 \%$ (Sulaiman et al. 2018). The number of pepper production in Vietnam remains increasing from year to year while Indonesia is otherwise.

Not only the price of pepper declined but also the production of pepper decreased. Badan pusat statistik (2019) showed that between 2014 and 2018, the pepper production in seven regencies in the province went down. The exception was in Bangka Tengah whereby it increased.

The phenomena figures that the business performance of pepper decreases. There are some factors that affect the business performance. Witjaksono, (2014) and Zebua (2017) explain that the competitive advantage post-harvest, and market orientation are variables that determine the business performance. Muntok white pepper has its competitive advantage as it supports with the geographical indication.

The pepper is spicy and aromatic. Komite Ekonomi and Industri Nasional Republik Indonesia (2018) describes that the pepper has about 6-7\% of spicy level. The advantage 
can be used as a solution to improve the business performance of pepper. Thus, study aims to understand the effect of market orientation, post-harvest treatment, and ability of farmer in creating competitive advantage towards the competitive advantage.

\section{METHODS OF RESEARCH}

Bangka Selatan and Bangka were the location of the study. Primary and secondary data were the type of data. Survey was applied as the research method, involving 60 farmers as the respondent. Simple random sampling was employed to determine the sampling method. Both qualitative and quantitative descriptive were used to analyze the data.

Microsoft Excel 2010 and Structural Equation Modelling (SEM) analysis with smart partial least squares (PLS) 3.0 version were used to process the quantitative data. Two stages of data analysis process applied: outer model analysis or known as measurement model and inner model analysis or known as structural model.

The score of loading factor $(\lambda)$ was used in evaluating the measurement model. Valid was considered when the loading factor $(\lambda)$ was bigger than 0.5 . The significance test in the evaluation of structural model was based on the estimated value of the path parameter coefficient and t-value with bigger than 1.96. Those were conducted with using resampling method or known as bootstrapping. The variables of the study consisted of one latent variable, market orientation (X1), two endogenous variables, competitive advantage (Y2) and post-harvest process $(\mathrm{Y} 1)$, and 13 manifest variables.

The model of the study endeavored to answer three hypotheses: i) causal direct relationship between market orientation and competitive advantage $(\mathrm{H} 1)$, causal relationship between post-harvest and competitive advantage $(\mathrm{H} 2)$, as well as the causal indirect relationship between market orientation and competitive advantage through post-harvest. The research model can be seen as follows:

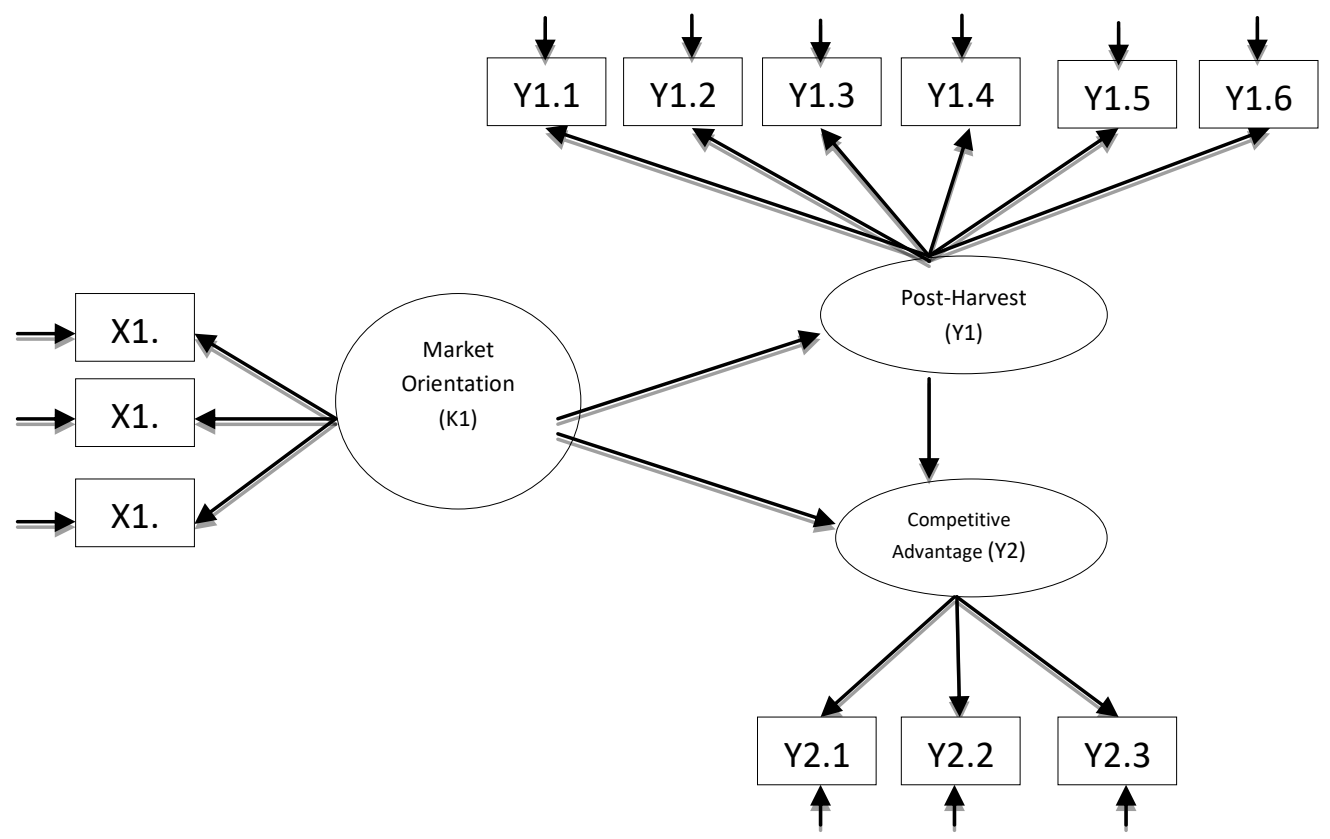

Figure 1 - Cross Diagram Model

\section{RESULTS OF STUDY}

Almost all regencies in Bangka Belitung Island Province produced the pepper. The respondents of the study were those farmers who involved with farmer groups in Desa Petaling Baru, Bangka and Desa Delas, Bangka Selatan.

Mostly, smallholder plantation dominated the pepper farming activity in the province. Table 1 figured that $96.67 \%$ of respondents considered the farmer as their main job. 
The age of respondents was varying from 23 to 79 year-old. The average age of the respondent was 41 . Majority of them was graduated in high school. The average experience of farming activity was 20 years.

Table 1 - Characteristics of Respondent by education, age, experience, and livelihood

\begin{tabular}{llll}
\hline Characteristics & Group & Frequency (person) & Percentage (\%) \\
\hline \multirow{4}{*}{ Age } & $22-36$ & 21 & 35,00 \\
& $37-51$ & 29 & 48,33 \\
& $52-66$ & 9 & 15,00 \\
& $67-81$ & 1 & 1,67 \\
\multirow{5}{*}{ Education } & No Formal School & 4 & 6,67 \\
& Elementary School & 14 & 23,33 \\
& Junior High School & 15 & 25,00 \\
& Senior High School & 23 & 38,33 \\
& Diploma & 1 & 1,67 \\
\multirow{2}{*}{ Farming Experience (year) } & Degree & 3 & 4,00 \\
& $2-18$ & 26 & 50,00 \\
& $19-35$ & 30 & 5,00 \\
& $36-52$ & 3 & 1,67 \\
\hline \multirow{2}{*}{ Pepper farming as the livelihood } & $53-69$ & 1 & 96,67 \\
& Main & 58 & 3,33 \\
\hline
\end{tabular}

The Effect of Market Orientation and Post-Harvest Treatment towards the Competitive Advantage with the Structural Equation Modelling Approach. The data was analyzed by using Structural Equation Modelling with smart partial least squares. Two stages of the process were applied: i) outer model analysis or known as measurement model; and ii) inner model analysis or known as structural model. The evaluation of measurement model was applied by identifying the loading factor $\operatorname{score}(\lambda)$. It was considered as valid when the loading factor score was bigger than 0.5 .

Table 2 - The Contribution of Indicator Variable by the Score of Loading Factor, T-Value, Composite Reliability and Average Variance Extracted

\begin{tabular}{|c|c|c|c|c|c|c|}
\hline Latent Variable & Manifest Variable & $\begin{array}{l}\text { Loading } \\
\text { Factor }\end{array}$ & $\begin{array}{l}\text { T- } \\
\text { value }\end{array}$ & $\begin{array}{l}\text { Composite } \\
\text { Reliability }\end{array}$ & AVE & Note \\
\hline Market Orientation (X1) & $\begin{array}{l}\text { Customer orientation } \\
\text { (X1.1) } \\
\text { Competitor orientation } \\
\text { (X1.2) } \\
\text { Market information } \\
\text { (X1.3) }\end{array}$ & $\begin{array}{l}0.779 \\
0.519 \\
0.739\end{array}$ & $\begin{array}{l}9.518 \\
3.127 \\
6.398\end{array}$ & 0.725 & 0.921 & $\begin{array}{l}\text { Valid and } \\
\text { Reliable } \\
\text { Valid and } \\
\text { Reliable } \\
\text { Valid and } \\
\text { Reliable }\end{array}$ \\
\hline $\begin{array}{l}\text { Post-Harvest Treatment } \\
\text { (Y1) }\end{array}$ & $\begin{array}{l}\text { Sorting (Y1.1) } \\
\text { Grading (Y1.2) } \\
\text { Packaging (Y1.3) } \\
\text { Labeling (Y1.4) }\end{array}$ & $\begin{array}{l}0.604 \\
0.824 \\
0.685\end{array}$ & $\begin{array}{l}5.198 \\
12.10 \\
6.040 \\
7.218\end{array}$ & 0.806 & 0.513 & $\begin{array}{l}\text { Valid and } \\
\text { Reliable } \\
\text { Valid and } \\
\text { Reliable } \\
\text { Valid and } \\
\text { Reliable } \\
\text { Valid and } \\
\text { Reliable }\end{array}$ \\
\hline $\begin{array}{l}\text { Competitive Advantage } \\
\text { (Y2) }\end{array}$ & $\begin{array}{l}\text { Competitive price(Y2.1) } \\
\text { Hard to copy (Y2.3) } \\
\text { Irreplaceable product } \\
\text { (Y2.4) }\end{array}$ & $\begin{array}{l}0.816 \\
0.880\end{array}$ & $\begin{array}{l}12.46 \\
37.05 \\
13.55\end{array}$ & 0.880 & 0.710 & $\begin{array}{l}\text { Valid and } \\
\text { Reliable } \\
\text { Valid and } \\
\text { Reliable } \\
\text { Valid and } \\
\text { Reliable }\end{array}$ \\
\hline
\end{tabular}

The main objective to evaluate the measurement model was to determine whether a particular indicator could certainly measure the construct (Ghozali I. 2006). Furthermore, the model evaluation also applied to test the reliability of a particular construct. The reliability test was conducted to show the accuracy and consistency of an instrument in measuring 
construct. The AVE score (0.5) and composite reliability (0.7) were used to determine reliability of a construct.

The evaluation of measurement model's analysis discovered that the model was valid and reliable. Table 2 illustrated that the loading factor scores of all observed variables were bigger than 0.5. It was supported with the AVE score and CR score which were bigger than 0.5 and 0.7 respectively. Both validity and reliability test were considered as satisfied. The final model was able to be used to the hypothesis test on the further evaluation of structural model.

The evaluation of structural model was applied to test the significance by using the estimating score of path parameter coefficient through resampling method. The score of the test was bigger than 1.96. The objective of the evaluation was to identify the relationship among latent construct, the estimating score of path parameter coefficient, and significance level (Latan and Ghazali, 2012).

Three relationship forms of the latent construct were evaluated: $\mathrm{H} 1)$ the direct effect of market orientation towards the competitive advantage; H2) the indirect effect of market orientation towards competitive advantage through post-harvest treatment; and $\mathrm{H} 3$ ) the effect of post-harvest treatment towards the competitive advantage. Table 3 figured the score of significance test from all established hypotheses in the study.

Table 3 - Path coefficient and Significance Test Score by Original Score of Sample and T-Value

\begin{tabular}{llll}
\hline Hypotheses & Original Sample & T- Value & Note \\
\hline $\mathrm{X} 1>\mathrm{Y} 1$ & 0.435 & $3.887^{*}$ & Significant \\
$\mathrm{X} 1>\mathrm{Y} 2$ & 0.391 & $3.141^{*}$ & Significant \\
$\mathrm{Y} 1>\mathrm{Y} 2$ & 0.354 & $3.442^{*}$ & Significant \\
\hline
\end{tabular}

${ }^{*}$ t significance (0.05):1.96).

All of the established hypotheses in the study were considered as significant. It meant that the hypotheses were accepted. The T-Value scores of all hypotheses were bigger than 1.96. It indicated that the market orientation and post-harvest treatment contributed in affecting the competitive advantage.

The original sample score showed how large the estimating scores of path parameter coefficient and the relationship of both variables. The larger coefficient score indicated that the impact of the estimating variable were stronger. In other words, the causal relationship was the most crucial thing in the model. Table 3 figured that market orientation and postharvest treatment had a positive impact towards the competitive advantage. It meant that if the attitude on market orientation and post-harvest treatment increased, the competitive advantage also increased.

Table 4 - The Score of the Impact of Market Orientation and Post-Harvest Treatment towards Competitive Advantage

\begin{tabular}{llll}
\hline \multirow{2}{*}{$\begin{array}{l}\text { The impact of market orientation towards competitive advantage through } \\
\text { post-harvest treatment }\end{array}$} & $\begin{array}{l}\text { Direct } \\
\text { Effect }\end{array}$ & $\begin{array}{l}\text { Indirect } \\
\text { Effect }\end{array}$ & $\begin{array}{l}\text { Total } \\
\text { Effect }\end{array}$ \\
\cline { 2 - 4 } & Competitive Advantage & \\
\hline Market Orientation & 0.391 & 0.154 & 0.545 \\
\hline Post-Harvest Treatment & 0.354 & - & 0.354 \\
\hline
\end{tabular}

${ }^{*}$ Actual influence at $\alpha 0.05$.

Fernando (2015) argued that in the case of flower, the post-harvest treatment was part of the activity to ensure the product was received by the consumer and was part of the standard operating procedure. Farmer should take into account the post-harvest treatment to meet the global need. Zebua (2017) and Hutchinson et al., (2003) explained that chrysanthemum cut flowers were able to be well-received by the consumer, it required to have best-practice in post-harvest treatment so that the quality of the product could be maintained. 
The post-harvest treatment had a direct and positive impact towards the competitive advantage with $35.4 \%$ of influence score. It illustrated that the post-harvest treatment was not the only variable to earn the product competitiveness. The variable became more relevant as muntok white pepper had its competitive advantage compared with other pepper in terms of taste, flavor, and level of spiciness. However, the competitive advantage was inadequate to ensure the product competitiveness as the international market competition were getting higher and the importing countries were stricter in providing the requirement of the agricultural commodities such as quality, cleanliness, and healthiness. The traditional post-harvest treatment such as immersion of pepper in the post tin-mining activity led to be contaminated by bacteria, roadside drying led to be contaminated with dust and animal waste, as well as no sorting process led to be contaminated with various impurities (Nurdjannah,2006).

The competitive advantage was a situation whereby a product was seen as better product compared with the competitor product (Saiman, 2015). The study found that the competitive advantage was directly and positively influenced by market orientation with the $39.1 \%$ of influence score. It indicated that the contribution of market orientation in forming the competitiveness was bigger than the post-harvest treatment.

The study also revealed that the market orientation had an indirect effect towards competitive advantage through the post-harvest treatment. The market orientation contributed $43.5 \%$ of influence score in influencing the post-harvest treatment and $15.4 \%$ of influence score in indirect effect towards competitive advantage. Hence, the influence score of market orientation in affecting the competitive advantage was $54.5 \%$. It meant that the attitude of farmers in the market orientation had a strategic role that improved the influence score of post-harvest treatment in acquiring the competitive advantage.

Zebua et al., (2017) stated that there was a positive impact of market orientation towards the post-harvest treatment. The chrysanthemum cut flower seller endeavored in ensuring the product met the need of the customer through post-harvest treatment. Fernando (2015) explained that the high quality product through post-harvest treatment offered the ability of product to compete with the others. Based on those scholars, to produce the product competitiveness of pepper, farmer should consider the post-harvest treatment whether it had followed the best practice or otherwise.

\section{CONCLUSION}

The competitive advantage was positively and significantly affected by market orientation both directly and indirectly through post-harvest treatment. The competitive advantage was also influenced by post-harvest treatment which was able to improve the impact of market orientation towards competitive advantage. The innovation on post-harvest treatment was inadequate to establish the product competitiveness. It required the attitude on market orientation to ensure the product competitiveness was gained. The farmer should earn more information about the market situation, understand the strength and weakness of competitor and identify the need of the customer.

\section{ACKNOWLEDGEMENTS}

The authors would like to thank University of Bangka Belitung (UBB) for funding support and facilities for making this study a success through Department Level of Lecturer Research 2020.

\section{REFERENCES}

1. Badan Pusat Statistik. (2019). Provinsi Kepulauan Bangka Belitung Dalam Angka 2019. Kepulauan Bangka Belitung: BPS Provinsi Kepulauan Bangka Belitung.

2. International Pepper Comunity. (2020, 04 14). Retrieved 04 17, 2020, from http://www.ipcnet.org/price/?p=d: http://www.ipcnet.org. 
3. Direktorat Tanaman Rempah and Penyegar. (2011). Rencana Strategis Direktorat Tanaman Rempah and Penyegar Tahun 2010-2014. Jakarta: Direktorat Tanaman Rempah and Penyegar Kementerian Pertanian.

4. Direktorat Jenderal Perkebunan Departemen Pertanian. (2019). Statistik Indikator Makro Sektor Pertanian. Jakarta: Kementrian Pertanian Republik Indonesia.

5. Fernando, A. R. (2015). Pengaruh PenerapanStandar Operasional Prosedur (SOP) terhadap Produktivitas Bunga Krisan. Skripsi. Yogyakarta: Universitas Pembangunan Nasional "Veteran".

6. Ghozali I. (2006). Struktural Equation Modeling: Metode Alternative Dengan Partial Least Square. Semarang: Badan Penerbit Undip.

7. Ghozali, I. Latan, H. (2012). Partial Least Square: Konsep, Teknik and Aplikasi SmartPLS 2.0 M3. Semarang: Badan Penerbit Universitas Diponegoro.

8. Heryanto M.A. , Nugraha A. (2018). Analisis Sistem Sosial-Ekologi Lada Putih Provinsi Kepulauan Bangka Belitung. Jurnal Agribisnis and Sosial Ekonomi Pertanian UNPAD. Vol. 3(02).

9. Nurdjannah N.(2006). Perbaikan Mutu Lada Dalam Rangka Meningkatkan Daya Saing di Pasar Dunia. Jurnal perspektf Vol 5 (1) $13-25$.

10. Riyanto. (2010). Pengawetan Bunga Potong Sedap Malam dengan Larutan PerakNitrat. Agri Sains, 1(2), 46-53.

11. Saiman, L. (2015). Kewirausahaan Teori, Praktik, and Kasus-Kasus. Jakarta: Salemba Empat.

12. Sulaiman A.A., Darwis V. (2018). Kinerja and Perspektif Agribisnis Lada Dalam Upaya Meningkatkan Kesejahteraan Petani. Jurnal Perspektif Vol. 17 (1):52-66.

13. Witjaksono H.P. (2014). Analisis orientasi kewirausahaan and sumber daya internal perusahaan terhadap kinerja melalui keunggulan bersaing. Jurnal bisnis strategi. Vol. 23 (1).

14. Zebua D.D.N. (2017). Pengaruhorientasi pasar terhadap penanganan pasca panen bunga ptong krisan di desa kenteng kecamatan bandungan kabupaten semarang.AGRIC jurnalaa ilmu pertanian Vol. 29(1):31-4. 